Elżbieta Woźnicka* iD http://orcid.org/0000-0002-6505-1058

Państwowa Uczelnia im. Stefana Batorego w Skierniewicach

https://doi.org/10.25312/2083-2923.18/2020_09ew

\title{
Przygotowanie do emerytury zadaniem współczesnej geragogiki
}

\begin{abstract}
Streszczenie: Przygotowanie się do emerytury, w dobie starzejącego się społeczeństwa, staje się problemem nie tylko jednostkowym, ale również społecznym. Staje się wyzwaniem dla geragogiki, a także dla polityki społecznej państwa czy działalności samorządów. Przygotowanie osób wchodzących w „trzeci wiek” do czasu na emeryturze stwarza im szansę na aktywne przeżywanie starości oraz ułatwienie życia w starzejącym się społeczeństwie. W niniejszym artykule koncentruję się na zależności między wykonywanym zawodem a obrazem własnej starości i przygotowaniem się do niej. Artykuł jest również próbą wskazania obszarów, w jakich powinno się odbywać przygotowanie do emerytury.

Słowa kluczowe: przygotowanie się do emerytury, przygotowanie się do starości, wychowanie do starości, aktywność seniorów, edukacja osób starszych
\end{abstract}

\section{Wstęp}

Zadaniem praktycznym współczesnej gerontologii jest wsparcie seniorów w zachowaniu przez nich jak najdłużej samodzielności i zapobieganiu negatywnym skutkom procesu starzenia się zarówno na poziomie jednostkowym, jak i społecznym. Pomocny w tym względzie może być proces przygotowania się do starości, $\mathrm{w}$ tym do emerytury. Przygotowanie (się) do starości w perspektywie jednostkowej polega na podjęciu przez pojedynczą osobę określonych działań z myślą o poprawie swojej sytuacji po

* Elżbieta Woźnicka - dr nauk humanistycznych w zakresie pedagogiki, absolwentka kierunku pedagogika na Wydziale Nauk o Wychowaniu Uniwersytetu Łódzkiego, adiunkt w Państwowej Uczelni im. Stefana Batorego w Skierniewicach, autorka publikacji z zakresu andragogiki, gerontologii społecznej. Publikuje m.in. w takich czasopismach, jak: „Edukacja Dorosłych”, „Rocznik Andragogiczny” i innych z zakresu edukacji dorosłych i gerontologii. Zajmuje się problematyką kształcenia dorosłych, aktywizacji osób starszych. Ponadto w swojej pracy podejmuje zagadnienia z zakresu pedagogiki opiekuńczo-wychowawczej oraz edukacji osób niesłyszących. 
przekroczeniu cezury wieku wyznaczającej starość. W perspektywie społecznej pojęcie to obejmuje działania podejmowane przez organ państwa, samorządy i instytucje społeczne, które są ukierunkowane na zaspokojenie w przyszłości potrzeb społeczeństwa, w którym wzrasta udział osób starszych. W niniejszym artykule przedstawię, jak jest postrzegany proces przygotowania do emerytury przez studentów kierunku pedagogika. Udzielę odpowiedzi na pytanie o to, jakie działania może podjąć jednostka, aby dobrze przygotować się do własnej starości i sprawić, by była ona pomyślna.

\section{Potrzeba przygotowania się do emerytury}

Okres starości w ostatnich dekadach uległ wydłużeniu. Dawniej życie na emeryturze trwało krótko. Gdy w 1889 roku kanclerz Niemiec Otto Bismarck wprowadził emerytury dla osób od 65. roku życia, nieliczni, którzy dożywali wówczas tego wieku, pobierali swoje świadczenia najczęściej tylko przez kilka lat ${ }^{1}$. Od tamtej pory średnia długość życia zdecydowanie się wydłużyła, na przykład w Polsce w roku 2019 wynosiła 81,8 lat dla kobiet i 74,1 dla mężczyzn². Zgodnie z danymi Eurostatu dla Polski kobiety, które żyją dłużej i przechodzą na emeryturę, mając tylko 56 lat, mogą na niej przebywać niemal 30 lat. Mężczyźni korzystają z przywilejów emerytalnych nieco krócej, bo około 15 lat (przechodzą na emeryturę w wieku 58,5 lat)³. Po przejściu na emeryturę uwalniają się ogromne zasoby wolnego czasu. Osoby, które osiągnęły wiek emerytalny, muszą pokonywać istotne trudności w zakresie orientacji i dostosowania się do tej fazy życia i nowych zadań rozwojowych. Dodatkowym utrudnieniem może być obraz samego siebie jako emeryta i wizerunek innych, mało aktywnych emerytów, oraz stereotypowe postrzeganie wieku emerytalnego. Takie doświadczenia nierzadko przeszkadzają w aktywnym życiu na emeryturze.

Do starości przygotowujemy się przez całe życie, począwszy od dzieciństwa, głównie poprzez rozwijanie i rozbudzanie zainteresowań, wdrażanie się do aktywności. W kolejnych fazach życia powinniśmy starać się, aby wraz z upływem lat te zainteresowania nie zniknęly i potem wypełniły czas na emeryturze. Ważne są również działania zapobiegające powstawaniu stereotypów dotyczących starości i osób starszych. Ze stereotypami trzeba walczyć lub je przełamywać, dlatego edukacją przygotowującą do okresu późnej dorosłości powinno się objąć już dzieci (istotna jest tu rola rodziny). Edukacja ta powinna rozwijać w młodym pokoleniu postawy i zachowania służące zdrowiu oraz kształtować właściwe postrzeganie zarówno starszych członków rodzi-

\footnotetext{
${ }^{1}$ C. Mech, Emerytury od Bismarcka, „Wprost” 2001, nr 1, https://www.wprost.pl/tygodnik/8889/Emerytura-od-Bismarcka.html [dostęp: 22.11.2020].

${ }^{2}$ Trwanie życia w 2019 roku, GUS, https://stat.gov.pl/obszary-tematyczne/ludnosc/trwanie -zycia/trwanie-zycia-w-2019-roku,2,14.html [dostęp: 22.11.2020].

${ }^{3}$ Życie kobiet i mężczyzn w Europie. Portret statystyczny, GUS, Unia Europejska 2017, https:// stat.gov.pl/kobiety-i-mezczyzni-w-europie/images/pdf/WomenMenEurope-DigitalPublication-2017 pl.pdf?lang=pl [dostęp: 29.11.2020], s. 4 .
} 
ny, jak i seniorów z najbliższego środowiska. Wpływ pozytywnego obrazu osób w podeszłym wieku na dzieci i młodzież będzie procentował w przyszłości, gdy młodzi się zestarzeją. Obraz ten znajduje też swoje odbicie w samopoczuciu obecnych seniorów, w ich podejściu do własnego wieku $u^{4}$ Przygotowanie do starości powinno współcześnie polegać na umożliwieniu młodemu pokoleniu stawienia czoła konsekwencjom starzejącego się społeczeństwa. W ten proces należałoby zaangażować nie tylko rodzinę, lecz także szkołę oraz inne instytucje oświatowe, kulturalne, a zadaniem programów nauczania winno być budowanie szacunku do osób starszych oraz podkreślanie ich ogromnej roli w społeczeństwie. Do procesu zdrowego, pozytywnego starzenia się może prowadzić wiele dróg. Jedna $\mathrm{z}$ nich będzie wiodła poprzez wspierające środowisko rodzinne i społeczne. O kilku drogach pozytywnego starzenia się piszą P. Błędowski, B. Szatur-Jaworska i M. Dzięgielewska ${ }^{5}$, zaliczają do nich:

- utrzymywanie niezależności życiowej,

- zachowanie sprawności fizycznej,

- zabezpieczenie finansowe,

- możliwości kształcenia się,

- utrzymywanie więzi społecznych,

- aktywność społeczną,

- zadowolenie, satysfakcję z życia.

W momencie przejścia na emeryturę wszelkie zainteresowania, aspiracje, umiejętności i doświadczenie, które nabywa się w procesie całożyciowej edukacji, powinny sprzyjać adaptacji do emerytury. Za proces przygotowania do niej powinny czuć się również odpowiedzialne instytucje kulturalno-oświatowe, zakłady pracy. Ważnym aspektem jest kształtowanie postawy szacunku wobec osób starszych i akceptacji procesu starzenia się wśród dzieci i młodzieży, przełamywanie stereotypów na temat starości i starzenia się. Promowanie zdrowego i aktywnego stylu życia to także istotny element przygotowania do starości, dlatego konieczne jest zachęcanie osób zbliżających się do emerytury lub emerytów aktywnych zawodowo do uczestnictwa w zajęciach sportowych, spotkaniach w domach kultury, uczęszczania na uniwersytety trzeciego wieku lub do innych form aktywności. Znaczącą rolę w procesie przygotowania do emerytury może odegrać edukacja dorosłych. Dzisiaj w tym obszarze wiele miejsca poświęca się problemom uczenia się przez całe życie, przygotowania do samodzielności, samookreślenia, emancypacji, rozwijania swojej osobowości, zdobywania nowych umiejętności i kwalifikacji. Należałoby dołączyć do tego nabywanie umiejętności przydatnych osobom starszym.

Aby zaplanować proces przygotowania się/wychowania do emerytury, powinno się określić cele tego przygotowania, uwzględnić indywidualne potrzeby, potencjały,

${ }^{4}$ A. Brzezińska, Społeczna psychologia rozwoju, Wydawnictwo Naukowe „Scholar”, Warszawa 2000, s. 114.

${ }^{5}$ B. Szatur-Jaworska, P. Błędowski, M. Dzięgielewska, Podstawy gerontologii społecznej, Oficyna Wydawnicza Aspra-Jr, Warszawa 2006, s. 179-180. 
doświadczenia ludzi, którym chcemy przyjść z pomocą. Przygotowując na starość, najpierw trzeba przyjrzeć się człowiekowi, któremu chcemy pomóc zmierzyć się z nią, jak również tym ludziom, którzy w związku z procesem starzenia się przeżywają trudności pozwalające nam dostrzec, jakiego rodzaju przygotowanie jest konieczne ${ }^{6}$.

Edukacja służąca przygotowaniu do emerytury powinna zawierać między innymi takie elementy, jak:

„- pomoc w antycypacji przebywania na emeryturze,

- rewizja oczekiwań nieadekwatnych do możliwości,

- pomoc w realistycznym wartościowaniu obecnej sytuacji życiowej i możliwych wersji przyszłości,

- pomoc w zachowaniu obecnych i odkrywaniu przyszłych obszarów aktywności,

- konkretyzacja planów i ich kontrola w odniesieniu do możliwości ich realizacji,

- informacje na temat procesu starzenia się,

- informacje na temat instytucji udzielających pomocy osobom starszym"7.

Edukacji dorosłych w kontekście przygotowania się do emerytury nie da się zaplanować w sposób uniwersalny. Należy za każdym razem wziąć pod uwagę potrzeby uczącego się: tego typu edukacja powinna mieć charakter informacyjny, refleksyjny, odnosić się do indywidualnych biografii, obejmować elementy uczenia się na podstawie własnych doświadczeń i przygotowywać do wypracowania nowych strategii zachowania. Wybierając takie podejście, nie uzurpujemy sobie prawa do planowania czyjegoś życia, lecz stwierdzamy, że można przygotować ludzi do emerytury w taki sposób, by przeżywali ją w miarę pogodnie, bez większych trudności i przeszkód ${ }^{8}$.

\section{Aleksander Kamiński i jego koncepcja przygotowania do starości}

Propagatorem wychowania do starości był Aleksander Kamiński, który głosił tezę „dodajmy życia do lat”. Według Kamińskiego „starcy są takimi, jakimi byli w młodszych latach [...] i aktywność w nich nie przyjdzie sama w wieku emerytalnym"

Kamiński wskazywał na zadania, jakie powinno się podejmować w konkretnych fazach życia:

- w okresie młodości i dorosłości jest odpowiedni czas na wyrabianie nawyków obcowania z kulturą, wykorzystania czasu wolnego oraz rozwijania możliwości adaptacyjnych,

${ }^{6}$ M. Dzięgielewska, Edukacja jako sposób przygotowania do starości, „Chowanna” 2009, nr 2, s. 56.

7 Tamże, s. 56.

8 Tamże, s. 60.

9 A. Kamiński, Funkcje pedagogiki społecznej. Praca socjalna i kulturalna, PWN, Warszawa 1982, s. 369-370. 
- w wieku przedemerytalnym należy przeznaczać więcej czasu na aktywność kulturalną, rozrywkową, rozwój zainteresowań, a także rozważania dotyczące kontynuacji pracy zawodowej w czasie emerytury,

- w okresie zadowalającej sprawności (do około 80. roku życia) autor postuluje wdrażanie do ulepszania życia przez zachęcanie do wyrobienia nawyków korzystnych dla zdrowia ludzi starszych (na przykład stosowania diety), udziału w życiu społecznym i kulturalnym oraz akceptacji tego, co nieuchronne,

- wokresie ograniczonej sprawności, gdy człowiek nie jest w stanie wyjść z domu bez pomocy innych, należy motywować do aktywności i kontaktów społecznych,

- w okresie starości niesprawnej, kiedy człowiek jest przykuty do łóżka, całkowicie uzależniony od pomocy i opieki innych, ważne, by rodzina i sąsiedzi utrzymywali kontakty z człowiekiem starszym: odwiedzali go i podejmowali z nim rozmowy na temat śmierci, informowali o życiu innych sędziwych osób, zachęcali do zachowania pogody ducha, a także przygotowali osobę starszą do zamieszkania w domu opieki w sytuacji, gdy istnieje taka konieczność ${ }^{10}$.

Proponowane przez Kamińskiego wychowanie do starości to najlepszy sposób na pogodzenie się z nią, a być może nawet coś więcej - jej zaaprobowanie, oczekiwanie na emeryturę jako okres życia mającego swoisty urok. Przygotowanie do tego etapu należy rozpocząć wcześnie, właściwie trwa ono przez całe dorosłe życie. Osobom w wieku przedemerytalnym proponował Kamiński rozwijanie postawy samowychowania. Chodzi o pobudzenie tendencji do akceptowania nadchodzącego trzeciego wieku i nowego w nim obrazu własnego ja, nowych reakcji na podniety wewnętrzne i zewnętrzne, o wyrabianie w sobie zdolności sprostania komplikacjom życiowym, o wyzwolenie nadchodzącej fazy życia z niepokojów, o włączanie się w nowe grupy i kręgi społeczne, o umacnianie poczucia, iż starość może być okresem pogodnego oraz wartościowego spożytkowania wolnego czasu, nadchodzących swobód, realizowania planów, na które dotychczas nie było czasu.

Kamiński szczególnie zalecał podejmowanie tradycyjnej działalności wychowawczej wobec tych osób w wieku emerytalnym, które w czasach młodości nie wyrobiły użytecznych nawyków w zakresie pracy, wczasowania, higieny i stosunków międzyludzkich. Mówił również o rozwijaniu działalności amatorskiej, zwłaszcza tej związanej z zainteresowaniami seniorów. Wychowanie do starości powinno się pojmować nie tylko jako informowanie, przekonywanie i zachęcanie, lecz także jako wywoływanie sytuacji sprzyjających określonemu postępowaniu. Elementem takiego wychowania jest aktywność wolnoczasowa, rozwijanie zainteresowań, ruch, hobby, aktywność amatorska, społeczna, polityczna, nauka zawodu rezerwowego, który można wykonywać po przejściu na emeryturę, nauczenie się higieny życia (ruch, sport, dieta

${ }^{10} \mathrm{Za}$ : A. Leszczyńska-Rajchert, Człowiek starszy i jego wspomaganie - w strone pedagogiki starości, Wydawnictwo Uniwersytetu Warmińsko-Mazurskiego, Olsztyn 2010, s. 34-35. 
itp.), rozszerzenie nawyków kulturalnych. Czas wolny emeryta może być poświęcony na czytanie książek, czasopism, słuchanie radia, oglądanie telewizji, bywanie na odczytach, koncertach, w klubach, korzystanie z szeroko rozumianych dóbr kultury, uczęszczanie do instytucji kulturalno-oświatowych, a także korzystanie z nowych technologii.

Dla Kamińskiego fundamentalnym elementem przygotowania do emerytury była praca nad sobą. To nadal bardzo aktualne ujęcie tematu, biorąc pod uwagę rozwijające się badania nad uczeniem się z własnej biografii. Kamiński zwracał uwagę, że „użyteczna praca i pozaosobiste zainteresowania to dwa główne eliksiry wydłużające młodość poza sześćdziesiątkę”. Wspominał również o „konieczności przygotowania do zawodu rezerwowego", niezbędnego w sytuacji wzrastających wymogów na rynku $\operatorname{pracy}^{11}$.

\section{Przygotowanie do emerytury wyzwaniem współczesnej gerontologii}

Obecnie wielu pedagogów, gerontologów, psychologów interesuje się nie tylko samą edukacją człowieka starszego, lecz także procesem uczenia się i przygotowania człowieka dorosłego do emerytury i starości. Przez całe życie człowiek dorosły rozwija swoją osobowość, pełni wiele ważnych ról, dąży do rozwoju, satysfakcji życiowej. Zdarza się jednak, że z tego wszystkiego rezygnuje po przejściu na emeryturę. Jednym z zadań współczesnej gerontologii jest zwrócenie uwagi na znaczenie potencjału zawodowego, twórczego, doświadczeń osób starszych. Ale jak go wykorzystać, czym i w jaki sposób mogą się dzielić osoby starsze na emeryturze? W jaki sposób efektywnie, pożytecznie i pomyślnie przeżywać swoją starość?

Rozwiązaniem może być świadome i zaangażowane przygotowanie się do emerytury i starości. Zdaniem B. Szatur-Jaworskiej zdrowemu oraz przemyślanemu przygotowywaniu się do późnej dorosłości sprzyjają takie czynniki, jak praca zawodowa, zabezpieczenie finansowe, dbałość o sprawność fizyczną i psychiczną, profilaktyka zdrowia, zachowanie i rozwijanie aktywności czasu wolnego, aktywności społecznej i politycznej, a także korzystanie z możliwości dalszej edukacji ${ }^{12}$. Zofia Szarota natomiast zwraca uwagę na proces planowania starości, w którym ważną rolę odgrywa profilaktyka pomyślnego starzenia się. Wdrażana od najmłodszych lat życia jednostek ma na celu opóźnienie postępów procesu starzenia się $e^{13}$.

Olga Czerniawska twierdzi, że człowiek dorosły przygotowuje się do emerytury, funkcjonując w różnych kręgach społecznych - takich jak rodzina, sąsiedztwo, pa-

11 A. Kamiński, dz. cyt., s. 369-370.

12 B. Szatur-Jaworska, P. Błędowski, M. Dzięgielewska, dz. cyt., s. 179.

13 Z. Szarota, Starzenie się i starość w wymiarze instytucjonalnego wsparcia, Wydawnictwo Uniwersytetu Pedagogicznego, Kraków 2010, s. 135-136. 
rafia, stowarzyszenie, grupa rówieśnicza, środowisko pracy - i pełniąc w nich różne role. Człowiek musi przygotować się do zmiany funkcjonowania w tych kręgach. Pełnione role społeczne po przejściu na emeryturę kończą się lub zmieniają. Przygotowanie do emerytury ma pomóc i inspirować, na przykład wypełnić lukę po utraconej roli pracownika ${ }^{14}$.

W obszarach przygotowania do starości ważna jest również sfera rozwoju duchowego człowieka. Problematykę tę porusza Artur Fabiś, wskazując na potrzebę wychowania duchowego do starości w obszarach przygotowania psychicznego i intelektualnego ${ }^{15}$. Gerontolodzy podkreślają istotę indywidualizacji procesu przygotowania się do starości, a także znaczenie przygotowania we wcześniejszych okresach życia. „Człowiek przygotowany w poprzednich fazach życia do starości akceptuje ją i odnajduje w niej potencjał do dalszego rozwoju" ${ }^{\prime \prime}$.

Socjolodzy, między innymi P. Szukalski ${ }^{17}$, zwracają natomiast uwagę na proces przygotowania się do emerytury, ale głównie z perspektywy globalnego starzenia się społeczeństwa. Z badań w ramach projektu międzynarodowego BALL - Be Active through Lifelong Learning wynika, że badani (emeryci i osoby pracujące) wskazywali na podobne obszary zagadnień kluczowych z ich punktu widzenia dla właściwego przygotowania się do emerytury. Należały do nich: zdrowie, zarządzanie czasem, rodzina i relacje społeczne. Obie podgrupy kojarzą aktywność na emeryturze z ćwiczeniami fizycznymi i podróżami. Tym, co różni obie grupy, jest fakt, że emeryci częściej wymieniają uczenie się (edukację pozaformalną i formalną) jako formę aktywnego starzenia się. Obie badane grupy deklarowały brak wiedzy na temat oferty zajęć edukacyjnych przygotowujących do emerytury w ich miejscu zamieszkania. Ten brak może wskazywać na konieczność organizowania zajęć przygotowujących do emerytury ${ }^{18}$.

Czemu ma służyć przygotowanie do emerytury? Po przejściu na emeryturę może pojawić się pustka, czas wcześniej systematycznie wypełniony, zorganizowany pozostaje do własnej dyspozycji emeryta. Dzięki odpowiedniej edukacji ostatnie dekady życia mogą być inne - bogatsze, pełniejsze, pogodniejsze, szczęśliwsze, można pomóc ludziom w nabyciu i rozwinięciu odpowiednich aspiracji, umiejętności i przyzwyczajeń, a także zainteresowań, które po nadejściu emerytury wypełnią czas wolny.

${ }^{14}$ O. Czerniawska, Drogi i bezdroża andragogiki i gerontologii, Wydawnictwo Wyższej Szkoły Humanistyczno-Ekonomicznej w Łodzi, Łódź 2000, s. 163-164.

15 A. Fabiś, J.K. Wawrzyniak, A. Chabior, Ludzka starość. Wybrane zagadnienia gerontologii społecznej, Oficyna Wydawnicza „Impuls”, Kraków 2015, s. 81-82.

16 Tamże, s. 82.

17 Zob. P. Szukalski (red.), Przygotowanie do starości. Polacy wobec starzenia się, Fundacja Instytut Spraw Publicznych, Warszawa 2009.

${ }^{18}$ M.D. Adamczyk, Przygotowanie do emerytury w kontekście rozwoju kapitału ludzkiego osób starszych - prezentacja wyników badania BALL - Be Active through Lifelong Learning, „Nierówności Społeczne a Wzrost Gospodarczy" 2017, nr 50(2), https://repozytorium.ur.edu.pl/bitstream/ handle/item/2772/24\%20adamczyk-przygotowanie $\% 20$ do\%20emerytury.pdf?sequence=1\&isAllowed=y [dostęp: 29.11.2020]. 
Współczesny świat bardzo odbiega od tego z lat młodości dzisiejszych emerytów. Dlatego tak ważne jest przygotowanie do czerpania z możliwości, jakie daje współczesny świat, korzystania z jego udogodnień, nowych technologii, rozwoju cywilizacyjnego. To, z jakim potencjałem, zdrowiem, zasobem potrzeb, zainteresowań, aspiracji ludzie wchodzą w wiek emerytalny, ma duży wpływ na ich losy, ale nie jest też bez znaczenia dla społeczeństwa jako całości. Dlatego warto, by przygotowanie do starości miało wymiar globalny, społeczny i było celem polityki społecznej państwa.

Prekursorskimi działaniami w ramach przygotowania do emerytury były staże przygotowujące do emerytury prowadzone w latach dziewięćdziesiątych XX wieku przez pracowników ówczesnego, kierowanego przez Olgę Czerniawską, Zakładu Oświaty Dorosłych Uniwersytetu Łódzkiego. Był to projekt polsko-francuski, opierający się na współpracy Uniwersytetu Łódzkiego z Uniwersytetem Lyon II. Celem projektu było ukazanie wzoru starości jako fazy życia, która składa się nie tylko z chorób, problemów, ale niesie wolność, wiąże się z aktywnością i samorealizacją ${ }^{19}$. W ramach projektu grupa polskich wykładowców została przeszkolona w Uniwersytecie Każdego Wieku w Lyonie w zakresie prowadzenia zajęć z przygotowania się do emerytury. Następnie w Łodzi w Związku Emerytów i Rencistów „Solidarność” odbyły się cztery staże, które koncentrowały się na procesach starzenia się i autorefleksji oraz propagowały działania na rzecz innych. Ukazano w nich sfery rozwoju człowieka w starości i nowy, rozwojowy, a nie redukcjonistyczny model starości.

\section{Przygotowanie się do emerytury w perspektywie wykonywanego zawodu}

Czy jakość życia na emeryturze uzależniona jest od naszej aktywności zawodowej? Jaka jest zależność między wykonywaną pracą zawodową a możliwościami jej kontynuacji na emeryturze? Czy umiejętności i doświadczenie zdobyte w pracy zawodowej mogą być wykorzystane po przejściu na emeryturę i jak się do tego przygotować? Jakie obszary powinno obejmować przygotowanie do emerytury? Tego typu pytania postawiłam studentom $\mathrm{w}$ ramach zajęć z gerontologii. Po przeanalizowaniu ścieżek wybranych zawodów podjęliśmy próbę charakterystyki procesu przygotowania do emerytury z perspektywy wykonywanej pracy, specyfiki podejmowanych zadań zawodowych. Zwrócę uwagę na kilka wybranych grup zawodowych, które w dyskusji pojawiały się najczęściej.

Nauczyciele. W opinii studentów nauczyciele to grupa osób zawodowo bardzo aktywnych, permanentnie podnoszących swoje kwalifikacje, uczących się. Zawód nauczyciela wymaga ogromnego zaangażowania w wypełnianie obowiązków, poczucia odpowiedzialności za uczniów. Po przejściu na emeryturę może pojawić się pustka

${ }_{19}$ Zob. B. Juraś-Krawczyk (red.), Przygotowanie do życia na emeryturze, Wydawnictwo Wyższej Szkoły Humanistyczno-Ekonomicznej w Łodzi, Łódź 1998; O. Czerniawska, dz. cyt., s. 164-166. 
związana z brakiem kontaktu z młodymi ludźmi, dziećmi. Zaproponowane przez studentów projekty przygotowujące nauczycieli do emerytury miałyby składać się zarówno z części teoretycznej, jak i praktycznej. Część teoretyczna powinna obejmować informowanie przyszłych seniorów o tym, co czeka ich na emeryturze. Jednym z zagadnień zaproponowanych przez studentów było planowanie budżetu, ponieważ emerytury nauczycielskie nie są wysokie. Wskazano również możliwości pracy dla nauczycieli na emeryturze: mogą udzielać korepetycji, podejmować inne dodatkowe prace.

Nauczyciele przygotowujący się do przejścia na emeryturę powinni odkrywać siebie, swoje zdolności, pogłębiać zainteresowania, poszukiwać nowych możliwości. Dlatego warto ich informować, gdzie szukać wydarzeń o charakterze kulturalno-oświatowym, które są szeroko dostępne (wystaw, odczytów, koncertów, prelekcji itp.), zachęcać do wyjścia do opery, teatru, kina, słuchania muzyki, czytania książek i czasopism.

Oczywiście przygotowanie do starości to nie tylko przekazywanie informacji i namawianie do aktywności, lecz także stwarzanie sytuacji, które mogą sprzyjać określonemu postępowaniu ${ }^{20}$. Dlatego nauczycieli warto zachęcić do prowadzenia projektów oswajających młodzież ze starością (dzielenia się swoim doświadczeniem). Kolejną atrakcyjną propozycją może być wolontariat: dzięki niemu emerytowany nauczyciel, któremu brakuje kontaktu z ludźmi, poczuje się potrzebny. Innym dobrym zajęciem dla nauczyciela seniora jest prowadzenie bloga lub programu na YouTube. Może to być blog związany z dotychczasową pracą, ale równie dobrze podróżniczy, kulinarny lub fotograficzny. Zawód nauczyciela powiązany jest z ustawicznym samokształceniem, dlatego znakomitym rozwiązaniem jest uczestnictwo w uniwersytetach trzeciego wieku zarówno w roli słuchacza, jak i wykładowcy.

Lekarze. Co dzieje się w życiu lekarza, który po latach ciężkiej pracy udaje się na emeryturę? Jak ma się odnaleźć w sytuacji, kiedy nagle przestaje być potrzebny? Co zrobić, aby taki senior mógł mieć godną i satysfakcjonującą starość? Bycie lekarzem wiąże się z byciem użytecznym. Po przejściu na emeryturę wykonujący ten zawód często czują się zbędni, z czym bardzo trudno jest im się pogodzić. Pojawia się pytanie, jak to zmienić. Dobrym rozwiązaniem byłoby wykorzystanie atutów lekarzy, czyli wiedzy i doświadczenia. Mogliby dzielić się doświadczeniem z młodymi lekarzami: udzielać się w grupach doradczych, w których mogliby konsultować diagnozy młodszych kolegów lub studentów medycyny. Innym wyjściem dla lekarza przygotowującego się do przejścia na emeryturę byłaby praca na pół etatu, niezbyt obciążająca. Starzejący się lekarze mogą też zrzeszać się w klubach czy organizacjach, które będą wsparciem dla młodszych lekarzy. Mogą angażować się w ten sposób, jeszcze pracując zawodowo i płynnie przejść do sytuacji, w której ograniczą się wyłącznie do doradztwa. Podobnie uczelnie wyższe, szkoły medyczne potrzebują nie tylko czynnych

${ }^{20}$ M. Dzięgielewska, dz. cyt., s. 53. 
praktyków, lecz także emerytowanych lekarzy z wieloletnią praktyką. Dzięki ich doświadczeniu i wiedzy studenci mogą zdobyć praktyczną wiedzę z pierwszej ręki. Także prowadzenie bloga medycznego byłoby bardzo dobrą formą dzielenia się doświadczeniem.

Pielęgniarki. Pracownicy ochrony zdrowia już podczas studiów zdobywają wiedzę na temat zabiegów zdrowotnych, właściwej diety oraz zachowania higieny. Wiedzą, jak ważna jest dbałość o ruch fizyczny i komunikacja międzyludzka, które pozwalają lepiej przystosować się do zmienionego środowiska. Poprawę sytuacji materialnej pielęgniarki na emeryturze przyniosłaby dodatkowa praca, ale pod warunkiem że nie będzie tak ciężka i trudna jak ta wykonywana przed przejściem na emeryturę.

Górnicy. Bardzo ciekawa grupa, wymagająca szczególnego przygotowania do emerytury. Górnicy są wyjątkowo przywiązani do etosu swojej pracy. To oni wszak stanowili „wiodącą siłę klasy robotniczej” w okresie realnego socjalizmu ${ }^{21}$. I miało to wymiar zarówno ekonomiczny, jak i społeczny. Praca jest dla górników wartością autoteliczną: to główny temat rozmów prowadzonych w domu i podczas spotkań towarzyskich. Górnicy mogą przejść na emeryturę po 25 latach pracy, często więc robią to osoby przed 50. rokiem życia. Po przejściu na emeryturę pojawia się pustka, którą trzeba zapełnić zadaniem równie ważnym społecznie jak praca. Ci, którzy mają takie możliwości, nadal pracują w zawodzie górnika, również za granicą.

Niestety wielu górników, którzy po przejściu na emeryturę spędzają czas głównie w domu (ewentualnie pracując dorywczo), zaczyna nadużywać alkoholu, ponieważ nie radzą sobie z utratą znaczącej pozycji społecznej. Często nie wiedzą, co zrobić z czasem wolnym, jaką aktywnością go wypełnić. Towarzyszy im poczucie odrzucenia, wrażenie, że nikt nie interesuje się ich dalszym losem. Osiedlom górniczym zagrażają patologie i ubóstwo. Rozwiązaniem byłoby wskazanie górnikom alternatywnych sposobów spędzania wolnego czasu. Należałoby pokazać, jak ważne jest znalezienie pasji, rozwijanie zainteresowań, którymi można potem wypełnić czas na emeryturze. Inne wyjście to przekwalifikowanie, poszukiwanie nowego zawodu, zgodnego z zainteresowaniami. Kształcenie zawodowe górników powinno uwzględniać treści związane z przygotowaniem do emerytury, bezrobociem, zagadnieniami spożytkowania czasu wolnego, możliwościami przekwalifikowania się, edukacją całożyciową.

Kierowcy. Studenci, którzy zwrócili uwagę na tę grupę, podkreślili, że po wielu latach pracy w zawodzie kierowcy często cierpią z powodu dotkliwych dolegliwości fizycznych. Dlatego najlepiej byłoby już na etapie kształcenia zawodowego badać predyspozycje przyszłych kierowców do innych zawodów, przygotowywać ich na ewentualną konieczność przekwalifikowania.

Pracownicy korporacji. Specyfiką dzisiejszego rynku pracy jest powstawanie wielu firm mających charakter korporacji, dużych przedsiębiorstw przemysłowych.

${ }^{21}$ U. Swadźba, Etos pracy grup zawodowych: na podstawie badań socjologów ślaskich, „Górnośląskie Studia Socjologiczne. Seria Nowa" 2010, nr 1, s. 272. 
Często zatrudniają one bardzo dużą liczbę osób z różnym wykształceniem, na różnych stanowiskach. Firmy te powinny zadbać o zdrowie pracowników, aby nie tylko byli wydajni w pracy, lecz także po przejściu na emeryturę mogli się realizować, spędzać czas aktywnie. Pracodawca, wiedząc, że pracownik przez długie lata pracy na swoim stanowisku traci siły i zdrowie, powinien to rekompensować zajęciami ruchowymi, sportowymi odbywającymi się na terenie firmy. Może pomyśleć o zorganizowaniu siłowni, zatrudnieniu specjalisty z zakresu profilaktyki zdrowia, zadbać o stałą i systematyczną opiekę lekarską dla pracowników. Dbałość o zdrowie i kondycję fizyczną w miejscu pracy sprawi, że pracownik na emeryturze nie będzie schorowany, zmęczony i niechętny do aktywności.

Ważne jest, aby pracownicy byli zachęcani do aktywnego spędzania czasu wolnego. Pracodawcy powinni organizować dla pracowników spotkania z ekspertami, którzy dokładnie przedstawiliby zalety płynące $\mathrm{z}$ aktywności fizycznej. Warto, by takie spotkania odbywały się systematycznie, aby zdobyta podczas nich wiedza była utrwalana oraz trafiała do coraz większej liczby pracowników. Dobrym przedsięwzięciem byłoby również organizowanie wycieczek, nie tylko mających charakter integracyjny, lecz także służących rozwijaniu zainteresowań turystycznych pracowników. Dzięki odbywającej się przynajmniej raz w roku wycieczce firmowej pracownicy mieliby możliwość złapania oddechu, oderwania się od rzeczywistości, zwiedzenia nowych miejsc.

Firma powinna zadbać również o psychologa, dostępnego dla wszystkich pracowników, ale szczególną opieką otaczającego tych, którzy w niedalekim czasie przejdą na emeryturę. Takim pracownikom posłużyłyby też spotkania, na których omawiano by kryzysy mogące pojawić się na emeryturze, ale także przedstawiano atrakcje, z jakich mogą oni korzystać w kolejnym etapie życia: kluby seniorów, wolontariat, chóry, organizacje itp. Warto też podczas takich spotkań uświadamiać pracownikom, że przejście na emeryturę to najlepszy moment na rozwijanie swoich pasji, na które nie było przedtem w życiu wiele miejsca. Lata spędzone na emeryturze można przeznaczyć na podróżowanie, uczenie się nowych rzeczy, rozwijanie swoich zdolności. Niektórzy mogą więcej czasu poświęcić wnukom, a tym samym odciążyć ich rodziców, inni odnajdą się w wolontariacie itp.

Firma powinna zadbać o to, by ludzie młodzi szanowali starszych: ich czas, poświęcenie, doświadczenie w pracy. Do pomysłów wartych rozważenia można zaliczyć wprowadzenie w firmie pracy dwuzmianowej dla osób po 60. roku życia (zamiast obowiązującej pozostałych pracy trzyzmianowej) czy wolnych od pracy weekendów. Młodych nauczyłoby to, że z wiekiem przychodzą przywileje, a starsi cieszyliby się większym komfortem pracy, a także zrozumieliby, że powoli zbliża się moment, w którym wiek zmusi ich do ustępowania miejsca młodym. Firmy powinny dostosowywać zakres i treść pracy do wieku pracownika: to, co bez problemu zrobi dwudziestolatek, może być problemem dla pięćdziesięcio- czy sześćdziesięciolatka.

Wypowiedzi studentów korelują z prowadzonymi dzisiaj w firmach działaniami związanymi z zarządzaniem wiekiem, mającymi na celu racjonalne i efektywne 
wykorzystanie posiadanych zasobów ludzkich. Uwzględnienie zróżnicowania w zakresie wieku pracowników może umożliwić pełne wykorzystanie wszystkich ich kompetencji, a przez to firma uzyska lepsze wyniki w ilości i jakości pracy ${ }^{22}$.

Wypowiedzi studentów dotyczyły jednostkowego ujęcia procesu przygotowania się do emerytury. Opierały się na rozumieniu tego procesu z perspektywy zawodów, które są im znane i bliskie. Przedstawione propozycje cechuje duży poziom ogólności, ale mogą być one przykładem obrazu starości w opinii osób w wieku 20-30 lat. Studenci w ramach podejmowania działań przygotowujących do procesu starzenia się wskazali na konieczność dalszej aktywności zawodowej na emeryturze, konieczność przygotowania się w sferze ekonomicznej oraz zdrowotnej poprzez zdrowy, aktywny tryb życia, w sferze społecznej poprzez podtrzymywanie relacji społecznych, w sferze edukacyjnej poprzez podejmowanie edukacji nie tylko w zakresie kompetencji informatycznych, ale również zaspokojenia swoich zainteresowań, nauki drugiego zawodu. W ich wypowiedziach nie zaistniał wymiar przestrzenny związany z poszukiwaniem na emeryturze nowego miejsca do mieszkania, przeorganizowania swojego dotychczasowego otoczenia.

\section{Podsumowanie}

Omówiono tylko wybrane grupy zawodowe, które były podstawą do dyskusji na temat przygotowania się do emerytury. Nasuwa się wniosek, że może być ono ukierunkowane przez wykonywaną pracę zawodową. Po analizie wypowiedzi i odbytej dyskusji nad zakresami przygotowania do emerytury z perspektywy wykonywanego zawodu można wyodrębnić kilka obszarów edukacji:

- aktywność edukacyjna oparta na rozwoju osobistym: wykłady, projekty, poznanie mapy edukacyjnej miejscowości, uniwersytety trzeciego wieku, kursy, rozwijanie pasji i hobby, zajęcia uświadamiające znaczenie rozwoju umysłowego dla utrzymania dobrej kondycji psychicznej, treningu pamięci,

- rozmowy na temat marzeń i pragnień dotyczących przyszłości, tworzenie listy rzeczy i marzeń do spełnienia podczas emerytury,

- zajęcia z cyklu „Jesteś potrzebny” uświadamiające rolę seniorów w społeczności, wskazujące, jak wiele emeryt może wnieść do społeczeństwa (odwiedzanie i wspieranie osób starszych, wykorzystywanie potencjału wiedzy do pomocy uczniom itp.),

${ }^{22}$ Zob. M. Cichorzewska, B. Mazur, A. Niewiadomska, E. Sobolewska-Poniedziałek, K. Zimnoch, B. Ziółkowska, Zarzadzanie wiekiem. Aspekt regionalny, instytucjonalny oraz organizacyjny, Wydawnictwo Politechniki Lubelskiej, Lublin 2015; G. Broniewska, Zarządzanie wiekiem i intermentoring jako metody dialogu międzypokoleniowego i kontynuacji rozwoju zawodowego pokolenia 50+, [w:] P. Kuźbik, M. Szymankiewicz (red.), Zarzadzanie organizacja z perspektywy metodologicznej: wybrane zagadnienia, Uniwersytet Łódzki, Łódź 2014, http://dspace.uni.lodz.pl/xmlui/bitstream/ handle/11089/31862/11-22\%20Broniewska.pdf? sequence=1\&isAllowed=y [dostęp: 22.11.2020]. 
- przygotowanie do zarządzania budżetem na emeryturze (układanie planów wydatków, poznanie sposobów oszczędzania pieniędzy, zaznajomienie się z możliwościami podjęcia dodatkowej pracy, wiedza o możliwościach uzyskania zniżek, niwelowanie zadłużeń i kredytów, unikanie kłopotliwych pożyczek),

- rozwijanie kompetencji cyfrowych (obsługa komputera, poszukiwanie informacji i robienie zakupów w internecie, korzystanie z portali społecznościowych, zapewnianie sobie bezpieczeństwa w sieci, uczące wykorzystania nowych technologii, między innymi internetu, przy załatwianiu spraw administracyjnych),

- zajęcia przygotowujące przyszłych seniorów do poznania ich podstawowych praw (obywatelskich, konsumenckich, pacjenta itp.),

- zajęcia fizyczne: przekazywanie wiedzy o wpływie ćwiczeń na zdrowie i dobrostan organizmu, obalenie mitów dotyczących zaprzestania aktywności fizycznej w wieku starszym, przedstawienie różnych form ćwiczeń, również tych, które można wykonywać w domu, podkreślenie aspektu społecznego udziału w zajęciach grupowych,

- zajęcia z dietetykiem: prowadzące do autorefleksji na temat sposobu odżywiania i jego wpływu na wszystkie aspekty życia, przygotowanie indywidualnych planów żywieniowych, prezentowanie interesującej literatury specjalistycznej, a także stron internetowych poruszających tę tematykę,

- „Zdrowie i choroba”: przygotowanie materiałów dotyczących chorób zawodowych oraz chorób wieku starszego, pogłębienie wiedzy na ten temat w celu obudzenia świadomości oraz zachęcenia do zmiany niezdrowego stylu życia,

- przygotowanie domu: zajęcia dotyczące adaptacji miejsca zamieszkania do potrzeb osoby starszej, uczące, jak uczynić wnętrze funkcjonalnym z punktu widzenia emeryta ${ }^{23}$

- rozmowy na temat bezpieczeństwa osób starszych: informacje dotyczące ochrony przed oszustami, natarczywymi sprzedawcami; warsztaty z samoobrony,

- rozmowy trudne: przekazywanie informacji i nauka planowania przyszłości w trudnych sytuacjach życiowych (ciężka choroba, niepełnosprawność, przygotowywanie się na śmierć współmałżonka i przeżywanie żałoby, sporządzanie testamentu $)^{24}$.

Przygotowanie się do emerytury ma na celu między innymi zniwelowanie wpływu stereotypowego poglądu na starość. W polskim społeczeństwie nadal jest mocno

${ }^{23}$ Cały numer 1-2(15) czasopisma „Exlibris Biblioteki Gerontologii Społecznej”, zob. B. Bugajska, R. Iwański, Z. Szarota (red.), Gdzie mieszka starość. Przestrzeń - architektura - mieszkanie, „Exlibris Biblioteka Gerontologii Społecznej” 2018, nr 1-2(15), https://bgs.up.krakow.pl/wp-content/uploads/sites/54/2020/01/BGS-1-2-2018-B.BUGAJSKAR.IWA\%C5\%83SKIZ.SZAROTA-1. pdf [dostęp: 22.11.2020].

${ }^{24}$ Zob. A. Fabiś, Troski egzystencjalne w starości: ujęcie geragogiczne, Wydawnictwo Naukowe Uniwersytetu Pedagogicznego, Kraków 2018. 
zakorzenione kojarzenie go z biernym spędzaniem wolnego czasu, odpoczynkiem i pomaganiem rodzinie. Mimo specyficznych cech, problemów, ograniczeń starość powinna być postrzegana jako naturalny etap rozwoju człowieka, podobnie jak wcześniejsze fazy jego życia.

Z powyższych analiz wynika, że przygotowanie do emerytury może odbywać się na różne sposoby: poprzez czytanie literatury, refleksje nad własną biografią, rozmowy itp. Bardzo istotną rolę odgrywa analiza własnej kariery zawodowej i umiejętności zawodowych. Postulowane przez studentów działania zdolne zaktywizować emerytów dotyczą między innymi czerpania ze swoich umiejętności zawodowych, podjęcia trudu przekwalifikowania się, poszukiwania nowego zawodu lub zajęcia, w którym można wykorzystać dotychczasowe umiejętności i wiedzę. Starzejący się pracownik dysponuje różnymi sposobami przygotowania się do wejścia w nowy etap życia: może wziąć udział w warsztatach przygotowujących do emerytury, skorzystać $\mathrm{z}$ doradztwa emerytalnego lub testu zainteresowań, który wskaże, jak spożytkować czas wolny. Wyniki przeprowadzonych rozmów pokazują, że ogólny obraz starości wśród studentów jest raczej pozytywny, uwzględnia bowiem wykorzystanie czasu wolnego na aktywność edukacyjną, społeczną czy kulturalną. Emerytura kojarzy się z szansą na spełnienie marzeń, realizację planów, na które nie pozwalały wcześniej obowiązki zawodowe. Negatywne elementy obrazu starości to głównie obawy związane z przykrościami i dolegliwościami wieku podeszłego, które jednak pozostają na drugim planie.

Potrzeba przygotowania do emerytury jest dziś silniejsza niż kiedykolwiek wcześniej, bo podyktowana sytuacją demograficzną. Problem starzejącego się społeczeństwa stanowi wyzwanie zarówno dla andragogiki, geragogiki, jak i pedagogiki czasu wolnego oraz pedagogiki pracy. Istnieją jednak podstawy, by żywić nadzieję, że dzięki odpowiedniej edukacji przyszli emeryci będą przeżywać starość w sposób satysfakcjonujący dla siebie i pożyteczny dla społeczeństwa.

\section{Bibliografia}

Brzezińska A., Społeczna psychologia rozwoju, Wydawnictwo Naukowe „Scholar”, Warszawa 2000.

Cichorzewska M., Mazur B., Niewiadomska A., Sobolewska-Poniedziałek E., Zimnoch K., Ziółkowska B., Zarządzanie wiekiem. Aspekt regionalny, instytucjonalny oraz organizacyjny, Wydawnictwo Politechniki Lubelskiej, Lublin 2015.

Czerniawska O., Drogi i bezdroża andragogiki i gerontologii, Wydawnictwo Wyższej Szkoły Humanistyczno-Ekonomicznej w Łodzi, Łódź 2000.

Dzięgielewska M., Edukacja jako sposób przygotowania do starości, „Chowanna” 2009, nr 2.

Fabiś A., Troski egzystencjalne w starości: ujęcie geragogiczne, Wydawnictwo Naukowe Uniwersytetu Pedagogicznego, Kraków 2018. 
Fabiś A., Wawrzyniak J.K., Chabior A., Ludzka starość. Wybrane zagadnienia gerontologii społecznej, Oficyna Wydawnicza „Impuls”, Kraków 2015.

Juraś-Krawczyk B. (red.), Przygotowanie do życia na emeryturze, Wydawnictwo Wyższej Szkoły Humanistyczno-Ekonomicznej w Łodzi, Łódź 1998.

Kamiński A., Funkcje pedagogiki społecznej. Praca socjalna i kulturalna, PWN, Warszawa 1982.

Leszczyńska-Rajchert A., Człowiek starszy i jego wspomaganie - w stronę pedagogiki starości, Wydawnictwo Uniwersytetu Warmińsko-Mazurskiego, Olsztyn 2010.

Swadźba U., Etos pracy grup zawodowych: na podstawie badań socjologów śląkich, „Górnośląskie Studia Socjologiczne. Seria Nowa” 2010, nr 1.

Szarota Z., Starzenie się i starość w wymiarze instytucjonalnego wsparcia, Wydawnictwo Uniwersytetu Pedagogicznego, Kraków 2010.

Szatur-Jaworska B., Błędowski P., Dzięgielewska M., Podstawy gerontologii społecznej, Oficyna Wydawnicza Aspra-Jr, Warszawa 2006.

Szukalski P. (red.), Przygotowanie do starości. Polacy wobec starzenia się, Fundacja Instytut Spraw Publicznych, Warszawa 2009.

\section{Netografia}

Adamczyk M.D., Przygotowanie do emerytury w kontekście rozwoju kapitału ludzkiego osób starszych - prezentacja wyników badania BALL - Be Active through Lifelong Learning, „Nierówności Społeczne a Wzrost Gospodarczy” 2017, nr 50(2), https://repozytorium.ur.edu.pl/bitstream/handle/item/2772/24\%20 adamczyk-przygotowanie $\% 20$ do $\% 20$ emerytury.pdf? sequence $=1$ \&isAllowed=y [dostęp: 29.11.2020].

Broniewska G., Zarządzanie wiekiem i intermentoring jako metody dialogu międzypokoleniowego i kontynuacji rozwoju zawodowego pokolenia 50+, [w:] P. Kuźbik, M. Szymankiewicz (red.), Zarządzanie organizacja z perspektywy metodologicznej: wybrane zagadnienia, Uniwersytet Łódzki, Łódź 2014, http://dspace.uni.lodz.pl/xmlui/bitstream/handle/11089/31862/11-22\%20Broniewska. pdf? sequence $=1$ \&isAllowed $=y$ [dostęp: 22.11 .2020 ].

Bugajska B., Iwański R., Szarota Z. (red.), Gdzie mieszka starość. Przestrzeń - architektura - mieszkanie, „Exlibris Biblioteka Gerontologii Społecznej” 2018, nr 1-2(15), https://bgs.up.krakow.pl/wp-content/uploads/sites/54/2020/01/ BGS-1-2-2018-B.BUGAJSKAR.IWA\%C5\%83SKIZ.SZAROTA-1.pdf [dostęp: 22.11.2020].

Mech C., Emerytury od Bismarcka, „Wprost” 2001, nr 1, https://www.wprost.pl/tygodnik/8889/Emerytura-od-Bismarcka.html [dostęp: 22.11.2020].

Trwanie życia w 2019 roku, GUS, https://stat.gov.pl/obszary-tematyczne/ludnosc/ trwanie-zycia/trwanie-zycia-w-2019-roku,2,14.html [dostęp: 22.11.2020].

Życie kobiet i mężczyzn w Europie. Portret statystyczny, GUS, Unia Europejska 2017, https://stat.gov.pl/kobiety-i-mezczyzni-w-europie/images/pdf/WomenMenEurope-DigitalPublication-2017 pl.pdf?lang=pl [dostęp: 29.11.2020]. 


\section{Preparation for retirement as a task of modern geragogy}

Abstract: Preparing for retirement, in the age of an aging society, becomes not only an individual, but also a social problem. It becomes a challenge for geragogy, but also for the social policy of the state or the activity of local governments. Preparing people entering the "third age" for retirement gives them an opportunity to actively experience old age and facilitate life in an aging society. In this article, I would like to focus on the relationship between one's profession and the image of one's old age and preparation for it. The article is also an attempt to indicate the areas in which preparation for retirement should take place

Keywords: preparing for retirement, preparing for old age, upbringing for old age, activity of seniors, education of the elderly

\section{About the Author:}

Elżbieta Woźnicka - PhD in humanities in the field of pedagogy, graduate of pedagogy at the University of Lodz, Faculty of Educational Sciences, assistant professor at the State University. Stefan Batory in Skierniewice, author of publications in the field of andragogy and social gerontology. It publishes, among others in such magazines as Edukacja Dorosłych, Rocznik Andragogiczny and others in the field of adult education and gerontology. He deals with the issues of adult education and activation of the elderly. In addition, she deals with issues in the field of care and educational pedagogy and education of deaf people. 